\title{
PENGARUH MOTIVASI BERPRESTASI SERTA PENDIDIKAN DAN PELATIHAN TERHADAP PRESTASI KERJA
}

\author{
Kadek Nia Listyanti ${ }^{1}$ \\ A.A Sagung Kartika Dewi ${ }^{2}$ \\ ${ }^{1,2}$ Fakultas Ekonomi dan Bisnis Universitas Udayana (Unud), Bali, Indonesia \\ E-mail:nlistyanti@yahoo.com
}

\begin{abstract}
ABSTRAK
Prestasi kerja merupakan suatu hal yang harus diperhatikan dalam melaksanakan tugas demi tercapainya tujuan perusahaan. Penelitian ini bertujuan untuk mengetahui signifikansi pengaruh motivasi berprestasi serta pendidikan dan pelatihan terhadap prestasi kerja di PDAM Tirta Mangutama. Pengumpulan data dilakukan dengan penyebaran kuisioner dengan menggunakan skala likert 5 poin. Teknik analisis yang digunakan adalah regresi liniear berganda. Hasil analisis menunjukkan bahwa motivasi berprestasi berpengaruh positif dan signifikan terhadap prestasi kerja, serta pendidikan dan pelatihan berpengaruh positif dan signifikan tehadap prestasi kerja. Perusahaan harus memperhatikan aspek kinerja pegawai terlebih dilihat dari sikap professional dalam bekerja dan kesesuaian hasil pekerjaan dengan target yang telah ditetapkan. Sehingga apa yang menjadi tujuan, visi dan misi dari perusahaan dapat tercapai dengan baik. Pegawai diharapkan mampu meningkatkan motivasi berprestasi dengan menciptakan hubungan kerja yang baik dan meningkatkan kemampuan melalui pendidikan dan pelatihan sehingga pegawai mampu menyelesaikan masalah dalam pekerjaan dengan baik sehingga menghasilkan prestasi kerja. Kata Kunci: motivasi berprestasi, pendidikan dan pelatihan, prestasi kerja.
\end{abstract}

\begin{abstract}
Job performance is a matter that must be considered in carrying out the task in order to achieve company goals. This study aims to determine the significance of the influence of achievement motivation as well as education and training on work performance in PDAM Tirta Mangutama. Data collection is done by distributing questionnaires using a 5-point Likert scale. The analysis technique used is multiple linear regression. The results of the analysis show that achievement motivation has a positive and significant effect on work performance, and education and training have a positive and significant effect on work performance. Companies must pay attention to aspects of employee performance, especially seen from the professional attitude at work and the suitability of work results with the targets set. So that what is the goal, vision and mission of the company can be achieved well. Employees are expected to be able to increase achievement motivation by creating good working relationships and enhancing capabilities through education and training so that employees are able to solve problems in work properly so as to produce work performance.

Keywords: achievement motivation, education and training, work performance.
\end{abstract}




\section{PENDAHULUAN}

Semua perusahaan pasti memerlukan manajemen yang berkaitan dengan usaha- usaha untuk mencapai tujuan tertentu bagi perusahaan. Tidak hanya pada sektor swasta, sektor publik juga memerlukan manajemen yang baik agar dapat memberikan pelayanan yang baik kepada publik atau masyarakat yang memerlukan. Berhasil atau tidaknya suatu organisasi dalam mencapai tujuannya, tergantung oleh keberhasilan individu pada organisasi itu sendiri dalam menjalankan tugas mereka. Berbagai macam hambatan pasti akan ditemui oleh para individu organisasi untuk bisa bekerja dengan baik sehingga kinerja mereka dapat diterima dengan baik oleh perusahaan dan masyarakat yang memerlukan. Banyak faktor yang dapat mempengaruhi kinerja (prestasi kerja), antara lain: motivasi, kepemimpinan, lingkungan kerja, insentif, budaya kerja, komunikasi, jabatan, pelatihan, dan masih banyak yang lainnya.Semua faktor tersebut berpengaruh; ada yang dominan ada juga yang tidak (Munparidi, 2012). Oleh karena itu asset organisasi paling penting yang harus dimiliki oleh perusahaan dan sangat diperhatikan oleh manajemen adalah asset manusia dari organisasi tersebut dalam membantu tujuan perusahaan (Trianto \& Sugiharto, 2010).

Keberadaan sumber daya manusia di dalam suatu perusahaan memegang peranan sangat penting. Tenaga kerja memiliki potensi yang besar untk menjalankan aktivitas perusahaan (Krismasari \& Frianto, 2014). Potensi setiap sumber daya manusia yang ada dalam perusahaan harus dapat dimanfaatkan dengan sebaik - baiknya sehingga mampu memberikan output yang optimal. Menyadari begitu pentingnya pengelolaan SDM dalam mencapai tujuan organisasi maka perusahaan dan pimpinan perlu meningkatkan perhatiannya terhadap pegawai dalam upaya meningkatkan prestasi kerjanya (Saani, 2013).

Badan Usaha Milik Daerah (BUMD) adalah perusahaan yang didirikan dan dimiliki oleh pemerintah daerah. Kewenangan pemerintah daerah membentuk dan mengelola BUMD ditegaskan dalam Peraturan Pemerintah No. 25 Tahun 2000 tentang kewenangan pemerintah dan kewenangan provinsi sebagai daerah otonom. Perusahaan Daerah Air Minum (PDAM) Badung merupakan layanan masyarakat dalam pembangunan daerah untuk meningkatkan pendapatan asli daerah dan sebagai sarana pengembangan dalam rangka pembangunan daerah khususnya dan pembangunan nasional umumnya. PDAM harus dikelola secara efisien dan efektif atas dasar prinsip - prinsip ekonomi perusahaan dengan tetap memperhatikan fungsi sosialnya. PDAM sebagai Badan Usaha Milik Daerah (BUMD) dalam melaksanakan tugas pokok dan fungsinya diisyaratkan memenuhi masing - masing fungsi teknis,ekonomis,sosial. Tugas yang telah terlaksana dengan baik merupakan cerminan dari sistem pendidikan dan pelatihan yang baik serta motivasi berprestasi yang tinggi sehingga menghasilkan prestasi kerja yang memiliki pengaruh terhadap kemajuan perusahaan. Hal ini menjadi kewajiban seorang pimpinan untuk dapat menciptakan suasanan yang dapat mendukung terciptanya prestasi kerja yang tinggi dari pegawai (Baharuddin et al., 2012).

Mangkunegara (2012:8) menyatakan istilah prestasi kerja berasal dari Job Performance atau Actual Performance ( prestasi kerja atau prestasi sesungguhnya yang dicapai seseorang). Pengertian kinerja (prestasi kerja) adalah hasil kerja secara kualitas dan kuantitas yang dicapai oleh seorang pegawai dalam 
melaksanakan tugasnya sesuai dengan tanggung jawab yang diberikan kepadanya (Umar, 2015). Tercapainya tujuan perusahaan tidak hanya tergantung pada peralatan modern, sarana dan prasarana yang lengkap, tetapi justru lebih tergantung pada manusia yang melaksanakan pekerjaan tersebut. Keberhasilan suatu organisasi sangat dipengaruhi oleh kinerja individu karyawannya.

Setiap organisasi maupun perusahaan akan selalu berusaha untuk meningkatkan prestasi kerja karyawan, dengan harapan apa yang menjadi tujuan perusahaan akan tercapai (Marwanto \& Nugroho, 2014). Dalam meningkatkan prestasi kerja karyawannya perusahaan menempuh beberapa cara yaitu melalui pendidikan, pelatihan, pemberian kompensasi yang layak, menciptakan lingkungan kerja yang kondusif dan pemberian motivasi (Anyim et al., 2012). Melalui proses - proses tersebut, karyawan diharapkan akan lebih memaksimalkan tanggung jawab atas pekerjaan mereka karena para karyawan telah terbekali oleh pendidikan dan pelatihan yang tentu berkaitan dengan implementasi kerja mereka. Sedangkan motivasi pada dasarnya adalah hak para karyawan dan merupakan kewajiban dari pihak perusahaan untuk mendukung kontribusi para karyawannya dalam rangka mencapai tujuan yang telah ditentukan (Odunlami \& Matthew, 2014).

PDAM Tirta Mangutama Kabupaten Badung memiliki pegawai yang membantu kelancaran perusahaan dalam mencapai tujuannnya tahun 2018 adalah sebanyak 205 pegawai. Dengan meningkatnya jumlah penduduk yang semakin pesat maka semakin banyak pula masyarakat yang memerlukan fasilitas air bersih dari perusahaan tersebut.Bagi organisasi yang memberikan pelayanan kepada publik, tentu saja kinerja (prestasi kerja) pegawai itu dapat dilihat dari bagaimana organisasi tersebut dalam memberikan pelayanan kepada publik, berdasarkan pengamatan terhadap keluhan masyarakat di media massa yang ditujukan ke PDAM, ternyata kualitas pelayanan dari perusahaan tersebut kurang memuaskan. Hal ini berdasarkan beberapa kritik maupun keluhan masyarakat sebagai pengguna jasa. Adapun keluhan pelanggan yang diperoleh melalui Website resmi PDAM Tirta Mangutama Kabupaten Badung diantaranya Pramadya Ardhino pada tanggal 7 Agustus 2018 mengeluhkan mengenai aliran air mati dan masih harus membayar tagihan dituliskan "sudah melakukan aduan melalui telepon, email dan sampai ke kantor pusat di Denpasar tidak bisa memberikan jawaban yang memuaskan dengan surat legal yang menerangkan aliran mati sampai kapan, hal ini terjadi dari maret $\mathrm{s} / \mathrm{d}$ mei dan sangat disayangkan bulan mei menimbulkan biaya pemakaian, setelah di konfirmasi dengan bagian keluhan pelanggan selalu dijawab "mohon tunggu" hingga tak ada jawaban lagi". Sri Haryaningsih pada tanggal 5 Mei 2018 menyampaikan "Tagihan tidak sesuai fakta : tagihan mei 2018 stand meter $=253 /$ pemakaian $25 \mathrm{~m} 3$. yang dicatat pd tgl 31 mei jmlh tagihan Rp. 166.165 padahal faktanya tgl 5 juni 2018 posisi stand meter 245, ada selisih $8 \mathrm{~m} 3$, kerja pihak pdam tidak professional dan sangat merugikan konsumen". Sarmida pada tanggal 6 Mei 2018 mengeluhkan "PDAM mati 1 Tahun : pernah lapor katanya alasannya perbaikan jalan sekarang tidak ada perbaikan jalan air masih mati, padahal tiap bulan bayar, saya minta pindah / pasang baru sudah 6 bulan sampai mei skrg tidak ada tanggapan jadi pdam tidak kooperatif". Adrianto E N pada tanggal 6 Mei 2018 mengeluhkan "Kami 
pelanggan PDAM di wilayah peumahan TM I Jimbaran sejak pertengahan April 2018, kondisi layanan air wilayah kami sangat kecil bahkan hanya bisa tertampung di tangki kami kurang dari $1 \mathrm{~m} 3$. Kami sudah melaporkan ke kantor namun tidak ada tanggapan sejak 2012. Mohon perhatian dan perbaikan karena ada 2 jalur pipa di gang lain sekeliling perumahan kami yang debit dan tekanan airnya jauh lebh besar. Dan dengan kondisi berebut air begini pun, kami harus membayar biaya layanan yang sama. Mohon perhatiannya segera".Suraji pada tanggal 6 April 2018 mengeluhkan "Air mati pada jam puncak : Pengaduan saya ini adalah yang ke sekian kalinya setelah pengaduan saya secara langsung dating ke kantor PDAm, pertama tanggal 29 September 2017, selanjutnya tanggal 23 Maret 2018 dan yang ketiga 3 April 2018, tentang keluhan air mati saat jam puncak, sekitar pukul 06.00 - 08.00 dan pukul 17.00 - 19.00 setiap hari. Namun keluhan tersebut sampai saat ini tidak ada tanggapan yang riil". Hal ini menunjukkan adanya kelambanan dalam menangani masalah, kurangnya tanggapan terhadap keluhan masyarakat, dan lain sebagainya. Penelitian Bonsu \& Kusi (2016) mengatakan belum maksimalnya pelayanan itu tentu tidak lepas dari kinerja (prestasi kerja) dari karyawan itu sendiri. Perusahaan idealnya mempunyai pegawai yang dapat menjalankan tugas dengan baik, produktif, bermotivasi tinggi , sabar dan bekerja keras, fokus pada detil, berpikir dan bertindak postif, dan menjaga hubungan sosial, sehingga prestasi kerja akan lebih baik dan maksimal.

Salah satu faktor yang mempengaruhi prestasi kerja karyawan adalah motivasi, dimana seseorang belum tentu bersedia untuk mengerahkan segenap potensi yang dimilikinya untuk mencapai hasil yang optimal, sehingga masih diperlukan adanya pendorong atau motivasi agar seseorang karyawan mau menggunakan seluruh potensinya (Osabiya, 2015). Motivasi adalah suatu faktor yang mendorong seseorang untuk melakukan suatu aktivitas tertentu (Sutrisno, 2011:109). Menurut Luviansi et al. (2012) motivasi merupakan hal yang paling penting bagi setiap organisasi pemerintah atau swasta. Motivasi sebagaimana diketahui bahwa merupakan dorongan batin yang menjadi titik tolak bagi setiap organisasi dalam melakukan sesuatu guna mencapai tujuan yang diinginkan (EK \& Mukuru, 2013). Jadi, prestasi kerja seorang pegawai akan lebih baik lagi apabila ditunjang dengan motivasi berprestasi. Karena motivasi berprestasi merupakan suatu dorongan dalam diri seseorang untuk melakukan atau mengerjakan suatu kegiatan atau tugas dengan sebaik-baiknya agar mencapai prestasi dengan hasil tertentu. Hal ini dikuatkan dengan pendapat McClelland bahwa motivasi berprestasi (need for achievement) merupakan salah satu kebutuhan individu. Jadi, motivasi berprestasi pada penelitian ini terkait kepada kebutuhan dan tujuan pada setiap pegawai di perusahaan. Pegawai akan mampu mencapai prestasi kerja maksimal jika ia memiliki motivasi berprestasi tinggi. Motivasi berprestasi yang perlu dimiliki oleh pegawai harus ditumbuhkan dari dalam diri sendiri selain dari lingkungan kerja. Hal ini karena motivasi berprestasi yang ditumbuhkan dari dalam diri sendiri akan membentuk suatu kekuatan diri sehingga pencapaian prestasi kerja akan lebih mudah.

Berkaitan dengan motivasi berprestasi di PDAM dirasakan masih kurang. Dibuktikan pada keluhan pelanggan yang terjadi dan didukung berdasarkan wawancara dan dengan pegawai bagian umum dan personalia sebanyak 10 orang 
dimana 3 diantaranya yaitu Made (nama asli disamarkan) dalam wawancara menyatakan "banyak pegawai yang datang terlambat, dan bahkan ada beberapa diantara mereka datang ke kantor hanya sekedar memenuhi absen saja dan kurang serius dalam melaksanakan tanggung jawabnya”. Hal ini juga diakui oleh salah satu pegawai Komang (nama asli disamarkan) dalam wawancara menyatakan "dalam melaksanakan tugas dan pekerjaan sering menunda ,sehingga hal ini akan menghambat kelancaran dalam pekerjaan”. Dan terakhir pegawai ketiga Wayan (nama asli disamarkan) dalam wawancara menyatakan " kurangnya kesadaran dan disiplin pegawai dalam bekerja untuk mencapai tujuan organisasi". Hal tersebut membuktikan bahwa masih ada beberapa pegawai yang belum memiliki hasrat atau keinginan kuat untuk menjadi lebih baik. Tanggung jawab terhadap penyelesaian tugas masih kurang.

Selain motivasi berprestasi, pendidikan dan pelatihan juga berperan dalam meningkatkan prestasi kerja dimana pendidikan dan pelatihan merupakan salah satu upaya pembinaan pegawai saat bertugas dan merupakan faktor yang sangat berpengaruh dalam kualitas sumber daya manusia. Gorda, 2004:121) menyatakan bahwa pendidikan dan pelatihan sebagai suatu proses kegiatan dari suatu perusahaan untuk memperbaiki dan mengembangkan sikap dan perilaku keterampilan dan pengetahuan serta kecerdasan sesuai dengan keinginan dari perusahaan yang bersangkutan. Mangkuprawira (2013:134) mengemukakan bahwa pendidikan dan pelatihan adalah sebuah proses mengajarkan pengetahuan dan keahlian tertentu, serta sikap agar karyawan semakin terampil dan mampu melaksanakan tanggung jawabnya dengan semakin baik.

Program pendidikan dan pelatihan (diklat) sebaiknya direncanakan dengan cermat dan sesuai dengan kebutuhan organisasi pada masa saat ini maupun masa datang. Pegawai yang memperoleh program diklat dengan baik maka semakin baik kemampuannya dalam menyelesaikan pekerjaan. Supiatni (2011) menyatakan bahwa, diantara variabel kompensasi,diklat dan disiplin kerja variabel diklat memiliki pengaruh dominan terhadap prestasi kerja pegawai. Penelitian yang dilakukan oleh Moses (2011) menyebutkan, terdapat hubungan yang sangat tinggi antara diklat dan prestasi kerja seta menyebutkan jenis pelatihan, materi pelatihan dan waktu pelaksanaan pelatihan bila diberikan dengan baik akan meningkatkan prestasi kerja pegawai. Menyadari pentingnya pendidikan dan pelatihan di PDAM, perusahaan senantiasa melakukan peningkatan kinerja pegawai dengan mengadakan beberapa jenis diklat.

Namun program tersebut dirasakan belum maksial karena belum terdapat pendidikan dan pelatihan yang dirancang untuk mengurangi masalah - masalah yang menyebabkan keluhan - keluhan pelanggan. Hasil wawancara dengan Putu (nama asli disamarkan) menyatakan "Jadwal diklat yang terbentur dengan waktu kerja pegawai, sehingga dapat mengganggu operasional rutin pegawai". Ketut (nama asli disamarkan) juga mengatakan " terkadang materi diklat yang diberikan tidak sesuai dengan jenis pekerjaan yang ditekuninya". Made (nama asli disamarkan) yang menangani bagian diklat mengatakan " Dengan bertambahnya jumlah pegawai setiap tahunnya tidak dibarengi dengan penambahan jumlah pendidikan dan pelatihan yang diadakan". 
Achievement Motivation Theory atau Teori Motivasi Berprestasi merupakan pengembangan dari Need of Achievement Theory yang dikemukakan sebelumnya oleh Murray pada tahun 1970. Dari McClelland dikenal tentang teori kebutuhan untuk mencapai prestasi atau Need for Acievement (N.Ach) yang menyatakan bahwa motivasi berbeda-beda, sesuai dengan kekuatan kebutuhan seseorang akan prestasi. Murray sebagaimana dikutip oleh Winardi merumuskan kebutuhan akan prestasi tersebut sebagai keinginan :" Melaksanakan sesuatu tugas atau pekerjaan yang sulit. Menguasai, memanipulasi, atau mengorganisasi obyek-obyek fisik, manusia, atau ide-ide melaksanakan hal-hal tersebut secepat mungkin dan seindependen mungkin, sesuai kondisi yang berlaku. Mengatasi kendala-kendala, mencapai standar tinggi. Mencapai performa puncak untuk diri sendiri. Mampu menang dalam persaingan dengan pihak lain. Meningkatkan kemampuan diri melalui penerapan bakat secara berhasil."

David C. McClelland dalam teorinya menekankan bahwa kebutuhan seseorang itu terbentuk melalui proses belajar dan diperoleh dalam interaksinya dengan lingkungan. Pada teori ini disebutkan bahwa karakteristik individu dengan motivasi berprestasi yang tinggi yaitu didasarkan pada sebagian berikut : (1) keinginan menjadi yang terbaik; (2) membutuhkan umpan balik setelah melakukan suatu pekerjaan dan (3) Kreatif - inovatif dalam melakukan suatu tugas dan pekerjaan.

Prestasi kerja diartikan oleh Hasibuan (2013:105) sebagai suatu hasil kerja yang dicapai seseorang dalam melakukan tugas-tugas yang dibebankan kepadanya yang didasarkan tugas-tugas kecakapan, pengalaman serta kesungguhan dan waktu. Jawaban dari berhasil atau tidaknya tujuan organisasi yang telah di tetapkan ialah berasal dari prestasi kerja. Robbins \& Judge (2009:5) prestasi kerja adalah perbandingan antara penampilan seseorang dengan hasil yang diharapkan. Prestasi kerja merupakan salah satu tolak ukur untuk menentukan sukses tidaknya suatu perusahaan (McCormick \& Tiffin, 1974). Maier (1965) mengemukakan prestasi kerja sebagai kesuksesan seseorang dalam melaksanakan suatu pekerjaan.

Menurut (Hasibuan, 2013:105) indikator penilaian prestasi kerja adalah sebagai berikut. Hasil Kerja , Penilai menilai hasil kerja baik kualitas maupun kuantitas yang dapat dihasilkan oleh karyawan tersebut, kedisiplinan, penilai menilai disiplin karyawan dalam memenuhi peraturan - peraturan yang ada , mengajukan pekerjaannya sesuai dengan intruksi yang diberikan kepadanya, kreativitas, kemampuan karyawan dan mengembangkan kreativitas untuk menyelesaikan pekerjaannya, sehingga bekerja lebih berdayaguna, kerja Sama, kesediaan karyawan berpartisipasi dan bekerja sama dengan karyawan lain , sehingga hasil pekerjaan akan lebih baik, Kepribadian,sikap,perilaku,kesopanan,memberikan kesan yang menyenangkan, memperhatikan sikap yang baik dan penampilan simpatik serta wajar dari karyawan tersebut.

Motivasi berprestasi dirumuskan sebagai suatu kesungguhan atau daya dorong seseorang untuk berbuat lebih baik dari apa yang pernah dibuat atau diraih sebelumnya maupun yang dibuat atau diraih orang lain. Motivasi berprestasi termasuk jenis motivasi intrinsik. McClelland (1987) menyebutkan bahwa 
motivasi berprestasi adalah sebagai suatu usaha untuk mencapai hasil yang sebaik-baiknya dengan berpedoman pada suatu standar keunggulan tertentu (standard of exellence). Menurut Heckhausen (1967), motivasi berprestasi merupakan suatu usaha untuk meningkatkan kecakapan pribadi setinggi mungkin dalam segala kegiatannya dengan menggunakan ukuran keunggulan sebagai perbandingan. Jadi, dalam motivasi berprestasi selalu ada kriteria tertentu yang dijadikan tolok ukur kerberhasilan. Dalam hal ini, ada tiga kriteria, yaitu pertama, produk dinilai atas dasar kesempurnaan. Kedua, membandingkan prestasi sendiri yang pernah dicapai sebelumnya. Ketiga, membandingkan dengan prestasi orang lain dalam bidang sejenis.

McClelland menyebutkan adanya need for achievement disingkat $n$-Ach dan motif berprestasi pada diri individu. Motif berprestasi adalah keinginan untuk berbuat sebaik mungkin tanpa banyak dipengaruhi oleh kebanggaan dan pengaruh sosial, melainkan demi kepuasan pribadinya. Sementara $n$-Ach adalah dorongan untuk mencapai sukses gemilang, hasil yang sebaik-baiknya menurut standar terbaik. Menurut McClelland (Thoha, 2008: 236), seseorang dianggap memiliki motivasi berprestasi jika mempunyai keinginan untuk melakukan sesuatu karya dan prestasi yang lebih baik dari orang lain.

McClelland mengemukakan 6 karakteristik karyawan yang mempunyai motif berprestasi tinggi, yaitu sebagai berikut. Memiliki tingkat tanggung jawab yang tinggi, berani mengambil dan memikul resiko, memiliki tujuan yang realistik, memiliki rencana kerja yang menyeluruh dan merealisasikan, m emanfaatkan umpan balik yang kongkret dalam semua kegiatan, mencari kesempatan untuk merealisasikan rencana yang telah diprogramkan.

Pengertian Pendidikan menurut Undang-undang Republik Indonesia Nomor 2 Tahun 2003 "Pendidikan adalah usaha sadar dan terencana untuk mewujudkan suasana belajar dan proses pembelajaran agar peserta didik secara aktif mengembangkan potensi dirinya untuk memiliki kekuatan spiritual keagamaan, pengendalian diri, kepribadian, kecerdasan, akhlak mulia, serta keterampilan yang diperlukan dirinya, masyarakat, bangsa dan negara".

Pendidikan bagi pegawai merupakan sebuah proses mengajarkan pengetahuan dan keahlian tertentu serta sikap agar pegawai semakin terampil dan mampu melaksanakan tanggung jawabnya dengan semakin baik, sesuai dengan standar.Penyelenggaraan pendidikan dan pelatihan merupakan salah salah satu upaya untuk meningkatkan kualitas sumber daya manusia sesuai dengan kebutuhan pekerjaan. Dalam rangka meningkatkan sumber daya manusia pada setiap unit kerja juga akan berhubungan dengan hakikat pendidikan dan pelatihan.

Handoko ( 2008:103) menyatakan tujuan yang ingin dicapai dengan dilaksakannya pendidikan dan pelatihan dapat dirinci sebagai berikut. Pengikut diklat dapat melakukan pekerjaanya dengan lebih efisien, pengawasan yang dilakukan lebih sedikit karena karyawan mendapatkan pelatihan khusus dalam melaksakan tugasnya, maka lebih sedikit kesalahan yang dilakukannya, peserta diklat dapat lebih berkembang karena sulit bagi seseorang untuk mengembangkan dirinya tanpa ada suatu diklat yang khusus. Dengan diklat membuktikan bahwa pengembangan diri seseorang akan lebiih cepat, menstebalisasi pegawai atau untuk mengurangi labour turnover karena para karyawan yang mendapatkan diklat 
umumnya cenderung lebih lama bekerja dalam perusahaan yang memberikan kesempatan diklat, diklat bertujuan untuk mengurangi kerusakan barang, produksi, dan mesin-mesin karena karyawan semakin ahlii dan terampil dalam melaksanakan pekerjaannya serta mengurangi tingkat kecelakaan karyawan sehingga jumlah biaya pengobatan yang di keluarkan perusahaan berkurang.

Indikator-indikator yang berkaitan dengan pendidikan dan pelatihan menurut Mondy (2009) adalah sebagai berikut. Manfaat diklat adalah manfaat yang di rasakan oleh karyawan dengan adanya program diklat, materi diklat adalah bahan yang diberikan oleh pelatih atau infrastruktur dalam pelaksanaan program diklat, metode diklat adalah metode yang digunakan pelatih atau instruktur dalam menyampaikan materi diklat, informasi diklat adalah segala sesuatu berkaitan dengan penyebaran berita secara terbuka kepada semua karyawan mengenai diklat yang akan dilaksanakan perusahaan.

Pelatihan menurut Dessler (2009) adalah proses mengajarkan karyawan baru atau yang ada sekarang, keterampilan dasar yang mereka butuhkan untuk menjalankan pekerjaan mereka. Pelatihan merupakan salah satu usaha dalam dunia kerja. Pegawai, baik yang baru ataupun yang sudah bekerja perlu mengikuti pelatihan. Karena adanya tuntutan pekerjaan yang dapat berubah akibat perubahan lingkungan kerja, strategi, dan lain sebagainya.

Berdasarkan hasil penelitian McClelland menyimpulkan bahwa ada pengaruh yang positif antara motivasi berprestasi dengan pencapaian prestasi. Artinya karyawan yang mempunyai motivasi berprestasi tinggi cenderung memiliki prestasi kerja tinggi. Motivasi berprestasi yang tinggi akan tampil berupa kesediaan untuk bekerja keras dan sungguh-sungguh serta tekun untuk untuk mencapai kinerja (prestasi kerja) yang optimal (Wibawa \& Sriathi, 2017).

Penelitian Komara \& Nelliawati (2014) mengatakan bahwa peran motivasi merupakan salah satu faktor yang dapat memberikan pengaruh positif terhadap prestasi kerja karyawan. Luviansi et al. (2012) memberikan pendapat yang sama peran motivasi memberikan pengaruh positif terhadap prestasi kerja. Umar (2015) menemukan dalam penelitiannya hasil bahwa motivasi memberikan pengaruh positif terhadap prestasi kerja. Bonsu \& Kusi (2016) menyatakan motivasi memiliki pengaruh positif terhadap prestasi kerja karyawan. Hal yang sama dibuktikan oleh EK \& Mukuru (2013) motivasi memberikan pengaruh positif signifikan pada prestasi kerja pegawai.

Berdasarkan pendapat para ahli dan di buktikan dengan hasil penelitian sebelumnya cukup relevan untuk menarik kesimpulan sementara bahwa:

$\mathrm{H}_{1}$ : Motivasi berprestasi berpengaruh positif dan signifikan terhadap prestasi kerja.

Beberapa hasil penelitian mengkaitkan diklat berpengaruh terhadap prestasi kerja. Jagero et al. (2012) menyebutkan pelatihan kerja mempengaruhi pencapaian seorang pegawai, disamping itu penelitiannya menemukan pengetahuan dan keterampilan karyawan menjadi salah satu faktor lain yang mempengaruhi prestasi kerja. Giritama \& Suana (2014) dalam penelitiannya menunjukkan pendidikan dan pelatihan berpengaruh positif dan signifikan sebesar 0,179 terhadap prestasi kerja. Kristola \& Adnyani (2014) mengungkapkan bahwa 
pendidikan dan pelatihan berpengaruh positif sebesar 0,199 terhadap prestasi kerja. Hal serupa juga diungkapkan Putra \& Yuniari (2013) bahwa pendidikan dan pelatihan secara bersama - sama berpengaruh positif dan signifikan terhdap prestasi kerja.

Organisasi yang berinvestasi dalam jenis pelatihan dapat meningkatkan prestasi kerja, kompetensi dan keterampilan (Sultana et al., 2012). Ting et al. (2012) mengungkapkan bahwa pelatihan memiliki hubungan yang signifikan dengan prestasi kerja, oleh karena itu dapat disimpulkan bahwa guru memang membutuhkan semua program pelatihan yang dirancang oleh TED (Teacher Education Division). Nugraha \& Sriathi (2014) menemukan dalam penelitiannya bahwa diklat efektif untuk meningkatkan prestasi kerja karena diklat meningkatkan pengetahuan dan keterampilan.

Farooq \& Khan (2011) serta Saeed \& Asghar (2012) menyebutkan pelatihan dapat meningkatkan prestasi kerja pegawai. Elnaga \& Imran (2013) menambahkan pelatihan adalah faktor kunci untuk meningkatkan prestasi serta mengurangi perbedaan antara prestasi kerja yang dicapai dengan prestasi kerja yang ditargetkan. Diklat merupakan sarana untuk meningkatkan kualitas pegawai, sehingga diharapkan dapat meningkatkan penyelenggaraan pembangunan untuk kepentingan warga negara, disamping itu terdapat kaitan antara diklat dengan profesionalisme dan kompetensi serta meningkatkan efektifitas, efisiensi dan kualitas pelaksanaan tugas pegawai (Supriyatno, 2008). Penelitian Kamaliah (2007) semakin menguatkan bukti bahwa adanya pengaruh diklat terhadap prestasi kerja, apabila faktor - faktor diklat ditingkatkan maka prestasi kerja pegawai akan meningkat. Pegawai yang telah mengikuti diklat lebih mempunyai pengetahuan, keterampilan dan wawasan yang luas dibandingkan pegawai yang jarang mengikuti diklat.

Berdasarkan pendapat para ahli dan di buktikan dengan hasil penelitian sebelumnya cukup relevan untuk menarik kesimpulan sementara bahwa:

$\mathrm{H}_{2}$ : Pendidikan dan Pelatihan berpengaruh positif dan signifikan terhadap prestasi kerja.

\section{METODE PENELITIAN}

Variabel yang diteliti dalam penelitian ini adalah motivasi berprestasi $\left(\mathrm{X}_{1}\right)$ serta pendidikan dan pelatihan $\left(\mathrm{X}_{2}\right)$ sebagai variabel bebas, serta prestasi kerja (Y) sebagai variabel terikat. Lokasi penelitian ini dilakukan di PDAM Mangutama Kabupaten Badung yang beralamat di Jl. Bedahulu No. 3, Denpasar. Alasan penelitian ini dilakukan karena belum banyak yang melakukan penelitian di perusahaan tersebut mengenai sumber daya manusianya, dan diduga terdapat masalah yang menyangkut motivasi berprestasi, pendidikan dan pelatihan serta prestasi kerja pegawai di PDAM Mangutama Kabupaten Badung.

Populasi dalam penelitian ini adalah jumlah seluruh pegawai di PDAM Mangutama Kabupaten Badung. 
Tabel 2.

Jumlah Populasi

\begin{tabular}{ccc}
\hline No & Unit Kerja & Jumlah / Orang \\
\hline 1 & Bagian Umum & 35 \\
2 & Bagian Langganan & 16 \\
3 & Bagian Keuangan & 16 \\
4 & Bagian Produksi & 62 \\
5 & Bagian Distribusi & 59 \\
6 & Bagian Perencanaan Umum & 17 \\
& Jumlah & $\mathbf{2 0 5}$ \\
\hline
\end{tabular}

Sumber: PDAM Tirta Mangutama Kabupaten Badung, 2018

Apabila peneliti melakukan penelitian terhadap populasi yang besar, sementara peneliti ingin meneliti tentang populasi tersebut dan peneliti memeiliki keterbatasan dana, tenaga dan waktu, maka peneliti menggunakan teknik pengambilan sampel, sehingga generalisasi kepada populasi yang diteliti. Metode untuk menghitung penentuan jumlah sample dari populasi tersebut dengan menggunakan rumus slovin, sebagai berikut :

$$
\mathrm{n}=\mathrm{N} /\left(1+\mathrm{N} .(\mathrm{e})^{2}\right)
$$

Keterangan :

$\mathrm{n}=$ Jumlah Sampel

$\mathrm{N}=$ Jumlah Total Populasi

$\mathrm{e}=$ Batas Toleransi Error (5\%)

$\mathrm{N}=20$

Sehingga memperoleh sampel sebagai berikut :

$\mathrm{e}=5 \%$

Jadi, $\mathrm{n}=\mathrm{N} /\left(1+\mathrm{N}(\mathrm{e})^{2}\right)=205 /\left(1+205 \times 0,05^{2}\right)=135,53$ (dibulatkan) $\mathrm{n}=136$

Berdasarkan perhitungan rumus slovin diatas, jumlah sampel dalam penelitian ini sebesar 135,53 dibulatkan menjadi 136 orang. Metode penentuan sampel menggunakan proportionate stratified random samplingyang merupakan teknik pengambilan sampel anggota populasi yang dilakukan secara proporsional yaitu berdasarkan proporsional setiap bagian didalam instansi.

Berikut rumus proportionate stratified random sampling:

$$
\mathrm{S}=\frac{N i}{n} x N
$$

Keterangan :

$\mathrm{S}=$ Ukuran Sampel

$\mathrm{Ni}=$ Ukuran Populasi

$\mathrm{N}=$ Total Sampel

$\mathrm{N}=$ Total Populasi

Sampel diambil dari populasi yang akan ditentukan dengan metode stratified random sampling dapat dilihat pada Tabel 3. 
Tabel 3.

Jumlah Sampel Pegawai Masing-Masing Unit Kerja di PDAM Tirta Mangutama Kabupaten Badung

\begin{tabular}{|c|c|c|c|c|}
\hline No & Unit Kerja & $\mathrm{Ni}$ & $\begin{array}{c}\mathbf{F i} \\
(\mathrm{Ni}: \mathbf{N})\end{array}$ & $\begin{array}{c}\text { Jumlah Sampel } \\
(\text { Fi } \times \text { n) }\end{array}$ \\
\hline 1 & Bagian Umum & 35 & 0,17 & 23 \\
\hline 2 & Bagian Langganan & 16 & 0,08 & 11 \\
\hline 3 & Bagian Keuangan & 16 & 0,08 & 11 \\
\hline 4 & Bagian Produksi & 62 & 0,30 & 41 \\
\hline 5 & Bagian Distribusi & 59 & 0,29 & 39 \\
\hline 6 & Bagian Perencanaan Umum & 17 & 0,08 & 11 \\
\hline$\Sigma$ & & 205 & 1,00 & 136 \\
\hline
\end{tabular}

Sumber: Data diolah, 2018

Teknik analisis regresi linear berganda digunakan untuk menguji pengaruh motivasi berprestasi serta pendidikan dan pelatihan terhadap prestasi kerja. Persamaan regresi linear berganda dirumuskan secara matematis sebagai berikut:

Keterangan:

$$
\mathrm{Y}=\mathrm{a}+\mathrm{b}_{1} \cdot \mathrm{X}_{1}+\mathrm{b}_{2} \cdot \mathrm{X}_{2}+\mathrm{e} .
$$

$\mathrm{Y}=$ Prestasi kerja

$\mathrm{a}=$ konstanta

$\mathrm{X}_{1}=$ Motivasi berprestasi

$\mathrm{X}_{2}=$ Pendidikan dan Pelatihan

$\mathrm{b}_{1}=$ Koefisien regresi dari Motivasi Berprestasi $\left(\mathrm{X}_{1}\right)$

$\mathrm{b}_{2}=$ Koefisien regresi dari Pendidikan dan Pelatihan $\left(\mathrm{X}_{2}\right)$

$\mathrm{e}=$ Error of term (Variabel yang tidak terungkap)

\section{HASIL DAN PEMBAHASAN}

Penelitian ini menggunakan data primer yang didapat dari kuisioner yang dijawab oleh responden di PDAM Tirta Mangutama. Jumlah responden yang digunakan dalam penelitian ini adalah sebanyak 136 orang. Uraian tentang karakteristik responden menyangkut 3 aspek yaitu berdasarkan jenis kelamin, usia dan pendidikan terakhir.

Tabel 4. menunjukan bahwa pegawai dominan berjenis kelamin laki - laki sebanyak 103 orang dengan persentase 75,7 dan perempuan sebanyak 33 orang dengan persentase 24,3 dari total jumlah responden. Dengan demikian penempatan tenaga kerja pada PDAM Tirta Mangutama Badung lebih banyak mengangkat pegawai laki - laki dikarenakan pegawai yang ditugaskan lebih pada tugas di lapangan dan teknik. Tingkat usia dominan yang bekerja diperusahaan adalah dari usia 31-40 tahun, faktor usia dapat menunjang kegiatan perusahaan dalam menghasilkan jasa yang berkualitas. Selain umur produktif, pengalaman yang cukup juga diperlukan dan akan berkorelasi di dalam pencapaian tujuan perusahaan. Berdasarkan tingkat pendidikan SMA/SMK/D1 sebanyak 89 atau 65,4 persen , S1 berjumlah 36 orang atau 36 persen dan S2 sebanyak 4 orang atau 2,9 persen. Komposisi pekerja dari sudut pandang tingkat pendidikan cukup baik karena sebagian besar sudah pada level SMA keatas. 
Tabel 4.

Karakteristik Responden

\begin{tabular}{|c|c|c|c|c|}
\hline No & Variabel & Klasifikasi & Jumlah & Presentase $(\%)$ \\
\hline \multirow[t]{3}{*}{1} & Jenis kelamin & Pria & 103 & 75,7 \\
\hline & & Wanita & 33 & 24,3 \\
\hline & Jumlah & & 136 & 100 \\
\hline \multirow[t]{5}{*}{2} & Usia & 21-30 tahun & 34 & 25 \\
\hline & & $31-40$ tahun & 55 & 40,4 \\
\hline & & $41-50$ tahun & 36 & 26,5 \\
\hline & & $\geq 51$ tahun & 11 & 8,1 \\
\hline & Jumlah & & 136 & 100 \\
\hline \multirow[t]{7}{*}{3} & & SD & 2 & 1,5 \\
\hline & Pendidikan & SMP & 3 & 2,2 \\
\hline & & SMA/SMK/D1 & 89 & 65,4 \\
\hline & & D3 & 2 & 1,5 \\
\hline & & S1 & 36 & 26,5 \\
\hline & & S2 & 4 & 2,9 \\
\hline & Jumlah & & 136 & 100 \\
\hline
\end{tabular}

Sumber : Data diolah, 2018

Untuk menguji apakah data yang digunakan normal atau tidak dapat dilakukan dengan menggunakan uju Kolmogorov Sminarnov. Apabila koefisien Asym. Sig ( 2-tailed) lebih bear dari 0,05 maka data tersebut dikatakan berdistribusi normal.

Tabel 5.

Hasil Uji Normalitas Unstandardized Residual

\begin{tabular}{lrr}
\hline & Unstandardized Residual & 136 \\
\hline $\mathrm{N}$ & & .0000000 \\
Normal Parameters & Mean & .16805129 \\
& Std. Deviation & .112 \\
Most Extreme & Absolute & .112 \\
Differences & Positive & -.102 \\
& Negative & 1.308 \\
Kolmogorov-Smirnov Z & & .065 \\
Asymp.Sig (2-tailed) & &
\end{tabular}

Berdasarkan Tabel 5. dapat dilihat bahwa nilai Kolmogorov Sminarnov (KS) sebesar 1,308, sedangkan nilai Asymp. Sig. (2-tailed) sebesar 0,065. Hasil tersebut mengidentifikasikan bahwa model persamaan regresi tersebut berdistribusi normal karena nilai Asymp.Sig (2-tailed) 0,065 lebih besar dari nilai alpha 0,05 .

Uji ini bertujuan untuk menguji apakah pada model regresi ditemukan adanya kolerasi antar variabel bebas. Adanya multikoleniaritas dapat dilihat dari nilai tolerance atau variance inflation factor (VIF). Jika nilai tolerance lebih dari $10 \%$ atau VIF kurang dari 10, maka dikatakan tidak ada multikolinearitas.

Berdasarkan Tabel 6. dapat dilihat bahwa nilai tolerance dan VIF dari variabel motivasi berprestasi serta pendidikan dan pelatihan . Nilai tersebut menunjukkan bahwa nilai tolera nce untuk setiap variabel lebih besar dari 
10\% dan nilai VIF lebih kecil dari 10 yang berarti model persamaan regresi 2 bebas dari multikolinearitas.

Tabel 6.

Hasil Uji Multikoleniaritas

\begin{tabular}{llllllll}
\hline Model & \multicolumn{2}{l}{$\begin{array}{l}\text { Unstandardized } \\
\text { Coefficients } \\
\text { B }\end{array}$} & $\begin{array}{l}\text { Std. Error } \\
\text { Standardized }\end{array}$ & $\begin{array}{l}\text { t } \\
\text { Coefficients } \\
\text { Beta }\end{array}$ & & Sig & \multicolumn{2}{c}{ Collinearity Statistics } \\
& (Constant) & .399 & .119 & & 3.347 & .001 & \\
M. Berprestasi & .266 & .047 & .287 & 5.654 & .000 & .395 & 2.532 \\
Diklat & .613 & .045 & .689 & 13.569 & .000 & .395 & 2.532 \\
\hline
\end{tabular}

Sumber: Data diolah, 2018

Jika tidak ada satupun variabel bebas yang berpegaruh signifikan terhadap nilai absolute residual atau nilai signifikansinya diatas 0,05 maka tidak mengandung gejala heteroskedastisitas.

Tabel 7.

Hasil Uji Heteroskedastisitas

\begin{tabular}{|c|c|c|c|c|c|c|c|}
\hline \multirow{2}{*}{\multicolumn{2}{|c|}{ Model }} & \multicolumn{3}{|c|}{$\begin{array}{c}\text { Unstandardized } \\
\text { Coefficients }\end{array}$} & \multirow{2}{*}{$\begin{array}{c}\text { Standardized } \\
\text { Coefficients } \\
\text { Beta } \\
\end{array}$} & \multirow[t]{2}{*}{$\mathbf{t}$} & \multirow[t]{2}{*}{ Sig. } \\
\hline & & B & & Std. Error & & & \\
\hline 1 & (Constant) & & .141 & .075 & & 1.888 & .061 \\
\hline & M. Berprestasi & & .015 & .029 & .072 & .519 & .605 \\
\hline & Diklat & & -.017 & .028 & -.084 & -.608 & .544 \\
\hline
\end{tabular}

Sumber: Data diolah, 2018

Pada Tabel 7. dapat dilihat bahwa nilai Sig. dari variabel motivasi berprestasi serta pendidikan dan pelatihan masing - masing sebesar 0,605 dan 0,544 . Nilai tersebut lebih besar dari 0,05 yang berarti tidak terdapat pengaruh antara variabel bebas terhadap absolute residual. Dengan demikian, model yang dibuat tidak mengandung gejala heteroskedastisitas.

Adapun hasil pengujian analisis regresi linear berganda dari penelitian ini disajikan pada Tabel 9.

Tabel 9.

Rangkuman Analisis Regresi Linier Berganda

\begin{tabular}{|c|c|c|c|c|c|c|}
\hline \multirow{2}{*}{\multicolumn{2}{|c|}{ Model }} & & $\begin{array}{l}\text { dardized } \\
\text { ficients }\end{array}$ & $\begin{array}{l}\text { Standardized } \\
\text { Coefficients }\end{array}$ & \multirow[t]{2}{*}{$\mathbf{t}$} & \multirow[t]{2}{*}{ Sig. } \\
\hline & & B & Std. Error & Beta & & \\
\hline \multirow[t]{5}{*}{1} & (Constant) & .399 & .119 & & 3.347 & .001 \\
\hline & Motiv. Berprestasi & .266 & .047 & .287 & 5.654 & .000 \\
\hline & Diklat & .613 & .045 & .689 & 13.569 & .000 \\
\hline & Adjusted $\mathrm{R}^{2}$ & & & & & .863 \\
\hline & Sig. F & & & & & .000 \\
\hline
\end{tabular}


Hasil analisis pada Tabel 9 dapat dibuat persamaan regresi linear berganda sebagai berikut.

$$
\hat{\mathrm{Y}}=0,399+0,266 \mathrm{X}_{1}+0,613 \mathrm{X}_{2}+\mathrm{e}
$$

Motivasi berprestasi berpengaruh positif terhadap prestasi kerja pegawai. Nilai $\beta_{1}$ menunjukan bahwa ada pengaruh positif antara motivasi berprestasi dengan prestasi kerja pegawai sebesar 0,266.

Diklat berpengaruh positif terhadap prestasi kerja pegawai. Nilai $\beta_{2}$ menunjukan bahwa ada pengaruh positif antara dilat dengan prestasi kerja pegawai sebesar 0,613 .

Berdasarkan hasil analisis pengaruh motivasi berprestasi terhadap prestasi kerja diperoleh nilai Sig. $\mathrm{t}$ sebesar 0,000 dengan nilai koefisien beta 0,266 Nilai Sig.t 0,000 $<0,05$ mengindikasikan bahwa H0 ditolak dan $\mathrm{H} 1$ diterima. Hasil ini mempunyai arti bahwa motivasi berprestasi berpengaruh positif dan signifikan terhadap prestasi kerja.

Berdasarkan hasil analisis pengaruh pendidikan dan pelatihan terhadap prestasi kerja diperoleh nilai Sig. t sebesar 0,000 dengan nilai koefisien beta 0,613 Nilai Nilai Sig.t $0,000<0,05$ mengindikasikan bahwa H0 ditolak dan H1 diterima. Hasil ini mempunyai arti bahwa pendidikan dan pelatihan berpengaruh positif dan signifikan terhadap prestasi kerja.

Tabel 10.

Uji ANOVA

\begin{tabular}{cccccc}
\hline Model & $\begin{array}{c}\text { Sum of } \\
\text { Squares }\end{array}$ & df & $\begin{array}{c}\text { Mean } \\
\text { Square }\end{array}$ & F & Sig. \\
\hline Regression & 24.346 & 2 & 12.173 & 424.654 & .000 \\
Residual & 3.813 & 133 & & & \\
Total & 28.159 & 135 & & & \\
\hline Sumber: & Data & diolah 2018 & & &
\end{tabular}

Sumber: Data diolah, 2018

Tabel 10. menunjukkan nilai signifikan uji $\mathrm{F}$ sebesar 0,000 yang lebih kecil dari 0,05 . Karena nilai signifikansi uji $\mathrm{F}$ sebesar $0,000<0,05$ maka model regresi dinyatakan valid atau fit.

Dalam penelitian ini koefisien determinasi dilihat memalui nilai Adjusted $\mathrm{R}^{2}$. Adapun nilai dari Adjusted $\mathrm{R}^{2}$ pada penelitian ini telah disajikan pada Tabel 4.8 dapat dilihat bahwa nilai Adjusted $\mathrm{R}^{2}$ sebesar 0,863 dimana memiliki arti bahwa 86,3 persen variasi perubahan prestasi kerja dapat dijelaskan oleh variabel motivasi berprestasi dan diklat. Sedangkan sisanya sebesar 13,7 persen dipengaruhi oleh variabel lain diluar dari model penelitian.

Hipotesis pertama menyatakan bahwa motivasi berprestasi berpengaruh positif dan signifikan terhadap prestasi kerja. Artinya motivasi berprestasi berkorelasi positif dengan prestasi kerja pegawai PDAM Tirta MAngutama Kabupaten Badung. Semakin tinggi motivasi berprestasi maka prestasi kerja pegawai di PDAM Tirta Mangutama Kabupaten Badung akan meningkat dan sebaliknya, semakin rendah motivasi berprestasi pegawai maka prestasi kerja pegawai di PDAM Tirta Mangutama Kabupaten Badung akan menurun.

Hasil penelitian sesuai dengan penelitian sebelumnya yang dilakukan Penelitian Komara \& Nelliawati (2014) mengatakan bahwa peran motivasi 
merupakan salah satu factor yang dapat memberikan pengaruh positif terhadap prestasi kerja karyawan. Luviansi et al. (2012) memberikan pendapat yang sama peran motivasi memberikan pengaruh positif terhadap prestasi kerja. Umar (2015) menemukan dalam penelitiannya hasil bahwa motivasi memberikan pengaruh positif terhadap prestasi kerja. Bonsu \& Kusi (2016) menyatakan motivasi memiliki pengaruh positif terhadap prestasikerja karyawan. Hal yang sama dibuktikan oleh EK \& Mukuru (2013) motivasi memberikan pengaruh positif signifikan pada prestasi kerja pegawai.

Hasil penelitian hipotesis kedua menunjukkan bahwa pendidikan dan pelatihan berpengaruh positif dan signifikan terhadap prestasi kerja yang berarti apabila pendidikan dan pelatihan semakin tinggi maka prestasi kerja pegawai di PDAM Tirta Mangutama Kabupaten Badung akan meningkat dan sebaliknya, semakin rendah pendidikan dan pelatihan maka prestasi kerja pegawai di PDAM Tirta Mangutama Kabupaten Badung akan menurun.

Hasil penelitian sesuai dengan penelitian sebelumnya yang dilakukan Giritama \& Suana (2014) dalam penelitiannya menunjukkan pendidikan dan pelatihan berpengaruh positif dan signifikan sebesar 0,179 terhadap prestasi kerja. Kristola \& Adnyani (2014) mengungkapkan bahwa pendidikan dan pelatihan berpengaruh positif sebesar 0,199 terhadap prestasi kerja. Hal serupa juga diungkapkan Putra \& Yuniari (2013) bahwa pendidikan dan pelatihan secara bersama - sama berpengaruh positif dan signifikan terhdap prestasi kerja.

Farooq \& Khan (2011) serta Saeed \& Asghar (2012) menyebutkan pelatihan dapat meningkatkan prestasi kerja pegawai. Penelitian Kamaliah (2007) semakin menguatkan bukti bahwa adanya pengaruh diklat terhadap prestasi kerja, apabila faktor - faktor diklat ditingkatkan maka prestasi kerja pegawai akan meningkat.

Hasil penelitian ini memiliki implikasi teoritis dan praktis. Implikasi teoritis yang diperoleh dari penelitian ini adalah motivasi berprestasi serta pendidikan dan pelatihan berpengaruh positif dan signifikan terhadap prestasi kerja. Dengan demikian, hasil penelitian ini memberi dukungan empiris dan dapat dinyatakan memperkuat hasil-hasil studi terdahulu.

Implikasi praktis, memfokuskan pada kegunaan dan manfaat dari hasil penelitian untuk meningkatkan prestasi kerja pegawai PDAM Tirta Mangutama melalui motivasi berprestasi serta pendidikan dan pelatihan. Implikasi pertama yaitu diperoleh hasil bahwa untuk mencapai prestasi kerja pada PDAM Tirta Mangutama hendaknya perusahaan dari awal melakukan rekrutmen pegawai yang memiliki motivasi berprestasi yang tinggi dimana pegawai yang memiliki keinginan atau dorongan, kesungguhan untuk bekerja lebih unggul dan lebih baik yang berasal dari diri sendiri sehingga mampu meningkatkan kontribusi dalam kesuksesan perusahaan.

Implikasi kedua, yaitu diperoleh hasil bahwa pendidikan dan pelatihan pada PDAM Tirta Mangutama hendaknya dikaji lebih dalam lagi agar pendidikan dan pelatihan yang diadakan relevan untuk mengatasi keluhan yang terjadi pada pelanggan sehingga bermanfaat bagi peningkatan kemampuan dan wawasan pegawai dalam melaksanakan tugas di masing - masing bidangnya dan merupakan kesempatan yang terbaik untuk meningkatkan prestasi kerja. 
Penelitian ini hanya meneliti sebatas pada dua variabel saja yang sesuai dengan judul penelitian.Diharapkan pada penelitian selanjutnya dapat mengembangkan lagi variabel yang diteliti mengingat terdapat banyak variabel variabel lain yang mempengaruhi prestasi kerja, seperti lingkungan kerja dan kompensasi

Data penelitian dikumpulkan dari 136 pegawai PDAM Tirta Mangutama Badung, perlu dilakukan pengambilan data diluar lingkungan PDAM Tirta Mangutama Badung agar dapat di uji konsistensi temuan penelitian ini.

\section{SIMPULAN}

Motivasi berprestasi berpengaruh positif dan signifikan terhadap prestasi kerja. Hal ini berarti bahwa semakin tinggi motivasi berprestasi pegawai maka prestasi kerja PDAM Tirta Mangutama Badung akan meningkat.

Pendidikan dan Pelatihan berpengaruh positif dan signifikan terhadap prestasi kerja. Hal ini berarti bahwa semakin tinggi pendidikan dan pelatihan maka prestasi kerja pegawai PDAM Tirta Mangutama Badung akan meningkat.

Untuk meningkatkan prestasi kerja pegawai pihak manajemen PDAM Tirta Mangutama Badung harus memperhatikan kinerja pegawai dilihat dari sikap professional dalam bekerja dan kemampuan dalam menyelesaikan pekerjaan. Sehingga apa yang menjadi tujuan, visi dan misi dari perusahaan dapat tercapai dengan baik.

Pihak manajemen PDAM Tirta Mangutama Badung hendaknya merekrut pegawai yang memiliki aspek motivasi berprestasi yang tinggi yang memiliki keingginan dan dorongan untuk bekerja lebih dari standar yang ditetapkan sehingga mampu memperbaiki citra perusahaan melalui peningkatan prestasi kerja.

Proses pemberian materi dan metode dalam pendidikan dan pelatihan lebih diperhatikan agar sesuai dengan pekerjaan yang dimiliki oleh pegawai dan dalam penyampaian dapat dengan mudah dipahami serta perusahaan hendaknya memberikan pendidikan dan pelatihan yang relevan untuk mengatasi keluhan pelanggan karena hal tersebut sangat penting demi kelancaran pegawai dalam bekerja sehingga mampu menghasilkan prestasi kerja yang baik.

Saran bagi penelitian selanjutnya untuk dapat mengambil sampel diluar lingkungan industri air minum misalkan di industri perbankan dan industri kesehatan.

\section{REFERENSI}

Anyim, C. F., Chidi, O. C., \& Badejo, A. E. (2012). Motivation and Employees ' Performance in the Public and Private Sectors in Nigeria. International Journal of Business Administration, 3(1), 31-40. https://doi.org/10.5430/ijba.v3n1p31

Baharuddin, A., Alhabsyi, T., \& Utami, H. N. (2012). Pengaruh Pelatihan, Kompensasi, dan Disiplin Kerja terhadap Prestasi Kerja Karyawan (Studi Pada Kantor PT. PLN (Persero) Area Pelayanan dan Jaringan Malang). Jurnal Profit, 6(2), 56-68. 
Bonsu, C. A., \& Kusi, A. (2016). Effects of Motivation on job Performance of Local Government workers in Ghana: A case study of Atwima Nwabiagya District Assembly in the Ashanti Effects of Motivation on job Performance of Local Government workers in Ghana: A case study of Atwima Nwabia. International Journal of Management Sciences, 2(8), 337-350.

EK, K., \& Mukuru, E. (2013). Effect of Motivation on Employee Performance In Public Middle Level Technical Training Institutions In Kenya. International Journal of Advances in Management and Economics, 2(4), 73-82.

Elnaga, A., \& Imran, A. (2013). The Effect of Training on Employee Performance. European Journal of Business and Management, 5(4), 137147.

Farooq, M., \& Khan, M. A. (2011). Impact of Training and Feedback on Employee Performance. Far East Journal of Psychologyang Business, 5(1), 23-33.

Giritama, I. P. C., \& Suana, I. W. (2014). Pengaruh Pelatihan Kerja dan Kompensasi Terhadap Kepuasan Kerja serta Dampaknya Terhadap Prestasi Kerja Karyawan Koperasi Serba Usaha Kuta Mimba Di Kuta-Badung. EJurnal Manajemen Unud, 1066-1082.

Gorda, I. G. N. (2004). Manajemen Sumber Daya Manusia. Denpasar: Wirda Kriya Gematama.

Hasibuan, M. S. P. (2013). Manajemen Sumber Daya Manusia. Jakarta: Bumi Aksara.

Heckhausen. (1967). The Anatomy of achievement motivation. New York: Akademic Press.

Jagero, N., Komba, H. V., \& Mlingi, M. N. (2012). Relationship between on the Job Training and Employee's Performance in Courier Companies in Dar es Salaam, Tanzania. International Journal of Humanities and Social Science, 2(22), 114-120.

Kamaliah. (2007). Pengaruh Program Diklat terhadap Prestasi Kerja Pegawai Negeri di Kantor Dipenda Propinsi Riau. Arthavidya, 8(2), 287-294.

Komara, A. T., \& Nelliawati, E. (2014). Pengaruh Kompensasi, Motivasi dan Kepuasan kerja Terhadap Kinerja Pegawai Negeri Sipil (PNS) di Lingkungan Rumah Sakit Umum Daerah (RSUD) Kota Bandung. Jurnal Ekonomi, Bisnis \& Entrepreneurship, 8(2), 73-85.

Krismasari, D., \& Frianto, A. (2014). Pengaruh Kompensasi dan Disiplin kerja terhadap Prestasi Kerja Karyawan Pabrik Gula Tjoekir. Jurnal Ilmu Manajemen, 2(4), 1584-1592.

Kristola, D., \& Adnyani, I. G. A. D. (2014). Pengaruh Diklat dan Pengalaman Kerja Terhadap Prestasi Kerja Serta Dampaknya Terhadap Pengembangan 
Karir Pegawai di Balai Karantina Pertanian Kelas I Denpasar. E-Jurnal Manajemen Universitas Udayana, 902-921.

Luviansi, M., Djalil, A., \& Sambung, R. (2012). Analisis Pengaruh Motivasi terhadap Prestasi Kerja melalui Kepuasan dan Disiplin Kerja Pegawai (Studi Pada Universitas Palangka Raya). Jurnal Sains Manajemen, 1(1), 98-112.

Maier, N. R. F. (1965). Psychology in Industry. Boston: Houghtin Mifflin.

Mangkunegara, A. . A. P. (2012). Evaluasi Kinerja Sumber Daya Manusia. Bandung: PT. Refika Aditama.

Mangkuprawira, S. (2013). Manajemen Sumber Daya Manusia Stratejik. Jakarta: Ghalia Indonesia.

Marwanto, T. B., \& Nugroho, R. (2014). Pengaruh Kompensasi Dan Lingkungan Kerja Terhadap Motivasi Dan Disiplin Kerja Prajurit Di Satuan Kerja KRI X Armada RI Kawasan Timur. Jurnal Ilmu Ekonomi \& Manajemen, 1(1), 7482.

McClelland, D. C. (1987). Human Motivation. New York: Cambridge University Press.

McCormick, J. E., \& Tiffin, J. (1974). Industrial Psychology (Keenam). NewDelhi: Prentice-Hall of India Private Limited.

Moses, M. (2011). Pengaruh Pendidikan dan Pelatihan Penjenjangan terhadap Prestasi Kerja Pegawai Pada Dinas Koperasi dan UKM Kota Jayapura. Jurnal Analisis Manajemen, 5(2), 63-76. Retrieved from http://jurnal.umk.ac.id/index.php/JAM/article/view/8

Munparidi. (2012). Pengaruh Kepemimpinan, Motivasi, Pelatihan, dan Lingkungan Kerja Terhadap Kinerja Karyawan Pada Perusahaan Daerah Air Minum Tirta Musi Kota Palembang. Jurnal Orasi Bisnis, 7(1), 47-54.

Nugraha, I. G. N. W., \& Sriathi, A. A. A. (2014). Pengaruh Pendidikan dan Pelatihan (Diklat) dan Pengalaman Kerja Terhadap Prestasi Kerja dan Pengembangan Karir Pada Karyawan Baleka Beach Resort Badung. EJurnal Manajemen Unud, 3(8), 2167-2181. Retrieved from https://ojs.unud.ac.id/index.php/Manajemen/article/view/8285

Odunlami, I. B., \& Matthew, A. O. (2014). Compensation Management and Employees Performance in the Manufacturing Sector, A Case Study of a Reputable Organization in the Food and Beverage Industry. International Journal of Managerial Studies and Research (IJMSR), 2(9), 108-117.

Osabiya, B. J. (2015). The effect of employees motivation on organizational performance. Journal of Public Administration and Policy Research, 7(4), 62-75. https://doi.org/10.5897/JPAPR2014.0300

Putra, I. G. G. P., \& Yuniari, M. (2013). I Gede Gandi Pratam. E-Jurnal Manajemen Unud, 2(7), 751-766. 
Robbins, S. P., \& Judge, T. A. (2009). Perilaku Organisasi (12th ed.). Jakarta: Salemba Empat.

Saani, A.-J. (2013). Influence of Compensation and Supervision on Private Basic School Teachers Work Performance in Ashaiman Municipality. International Journal of Business and Social Science, 4(17), 64-69.

Saeed, M. M., \& Asghar, M. A. (2012). Examining the Relationship between Training, Motivation and Employees Job Performance - The Moderating Role of Person Job Fit. Journal of Basic and Applied Scientific Research, 2(12), 12177-12183.

Sultana, A., Irum, S., Ahmed, K., \& Mehmood, N. (2012). Impact of training on employee performance: A study of telecommunication sector in Pakistan. Interdisciplinary Journal Of Contemporary Research In Business, 4(6), 646661.

Supiatni, N. N. (2011). Pengaruh Kompensasi, Diklat dan Disiplin Kerja Terhadap Prestasi Kerja karyawan di Hotel Mercure Sanur. Jurnal Bisnis Dan Kewirausahaan, 7(2), 119-128.

Supriyatno. (2008). Pendidikan dan Pelatihan Aparatur Departemen Pekerjaan Umum. Jurnal Pendidikan Islam, 11(1), 47-62.

Sutrisno, E. (2011). Manajemen Sumber Daya Manusia (Ketiga). Jakarta: Kencana Prenada Media Grup.

Ting, S. K. T., Ying, C. Y., \& Salleh, N. S. B. M. (2012). Does Effectiveness of Training Program Influenced Teachers' Job Performance? Evidence from Malaysia. Journal of Education \& Vocational, 3(2), 173.

Trianto, A., \& Sugiharto, T. (2010). Effect of Compensation, Discipline, And Work Motivation on Employee Productivity of PT. Kukdong International. Jurnal Undergraduate Program, 1(4), 1-10.

Umar, A. (2015). The Effect of Motivation and Career Development Against Employeesâ $€^{\mathrm{TM}}$ Performance and Job Satisfaction of the Governor Office South Sulawesi Province, Indonesia. International Journal of Management Sciences, 5(9), 628-638. from http://rassweb.org/admin/pages/ResearchPapers/Paper 3_1497441403.pdf

Wibawa, I. G. P., \& Sriathi, A. A. A. (2017). Pengaruh Kompensasi, Motivasi dan Disiplin Kerja Terhadap Prestasi Kerja Karyawan. E-Jurnal Manajemen Unud, 6(12), 6763-6792. 